\title{
PENGARUH STRATEGI PEMASARAN TERHADAP FUNDING DAN LENDING DI BMT AT-TAJDID TEMAYANG BOJONEGORO
}

\author{
Nur Musfiah*1 \\ ${ }^{1}$ Mahasiswa Prodi Ekonomi Syari'ah Fakultas Agama Islam \\ Universitas KH. A. Wahab Hasbullah \\ Nurmusfia@gmail.com \\ Ashlihah, S.E., MM.*2 \\ 2 Dosen Prodi Ekonomi Syariah Fakultas Agama Islam \\ Universitas KH. A. Wahab Hasbullah \\ ashlihaherhaka@gmail.com \\ Arivatu Ni'mati Rahmatika, M.E.I.*3 \\ ${ }^{3}$ Dosen Prodi Ekonomi Syariah Fakultas Agama Islam \\ Universitas KH. A. Wahab Hasbullah \\ arivaturahmatika@gmail.com
}

\begin{abstract}
Baitul Mal Wat Tamwil is a sharia-based financial institution that manages the financial deposits and financing. Strategy in Marketing BMT At-Tajdid Temayang Bojonegoro Temayang planned to build community confidence that BMT At-Tajdid Temayang Bojonegoro is a business hall in which there are activities to develop Productive efforts and investments in improving the quality of economic activity and also building community confidence that at the BMT At-Tajdid Temayang Bojonegoro can manage the savings with the trust, but with the marketing strategy Whether BMT as a financial institution can compete with conventional financial institutions although the products, prices, places, and promotions have not been adequate so that the main problem will be observed by researchers. The results showed that the variable marketing strategy (product, price, place, promotion) simultaneously had an effect on funding and lending. It can be proved that the value F count $>$ F table or $99.847>4.20$. While based on a partial test of a variable marketing strategy the product has a significant effect on funding and lending, it can be proved that the product marketing strategy value T count more $>\mathrm{T}$ table or $3.709>2.059$, price $0.045>0.50$, place $0.240>0.50$, Promotion $2.205>2.059$. The results of this test resulted in a coesophageal determination $\left(R^{2}\right)$ of 0.963 That means $96.3 \%$ of the marketing strategy variable in the influence of variable funding and lending while the remaining $3.7 \%$ in the influence of other variables that are not conscientious in research This.
\end{abstract}

Keywords: Marketing Strategies, Funding, Lending 


\section{A. PENDAHULUAN}

Dalam perkembangannya, perbankan syari'ah yang berada dibawah naungan Bank Indonesia tidak bisa terlepas dari kegiatan ekonomi-ekonomi yang diikuti oleh lembaga keuangan bank lainnya yang berada dibawah naungan Bank Indonesia juga. ${ }^{1}$ Termasuk salah satu didalamnya Baitul Maal wa Tamwil atTajdid yang berada di daerah Temayang Bojonegoro.

Manajemen pengelolaan keuangan BMT At-Tajdid Temayang Bojonegoro dengan berbasiskan syari'ah sebenarnya sudah sesuai taraf kemampuan bersaing dengan lembaga penyimpanan dan pengelolaan keuangan lainnya. Akan tetapi dalam satu sisi, pandangan setiap individu terhadap pengelolaan keuangan berbasis syari'ah dan non syari'ah kurang begitu difahami oleh sebagian individu terutama individu lain yang kurang mendapatkan pengetahuan agamis khususnya syari'ah dan mu'amalah. Sehingga memunculkan berbagai persepsi dan asumsi bahwa BMT syari'ah dan lembaga keuangan lainnya itu sama saja. Hal ini yang menjadi tantangan bagi pihak BMT dalam kemampuan bersaing dengan lembaga lain yang berbasis non syari'ah.

Semakin banyaknya nasabah yang melakukan simpan pinjam di BMT AtTajdid Temayang Bojonegoro hal tersebut tentu akan semakin memicu ketatnya persaingan antar lembaga keuangan dalam mendapatkan nasabah. Dalam kondisi

\footnotetext{
${ }^{1}$ Arivatu Ni'mati Rahmatika dan Dunyati Ilmiah, "Analisis Sharih Akad Mudrobah dan Bay pada Sertifikat Investasi Mudharabah Antar Bank (SIMA)" dalam Proceedings of Annual Conference for Muslim Scholars, no. 1, 65-72, 2017.
} 


\section{PENGARUH STRATEGI PEMASARAN TERHADAP FUNDING DAN LENDING DI BMT AT-TAJDID TEMAYANG BOJONEGORO}

pesaingan yang semakin ketat BMT At-Tajdid Temayang Bojonegoro tidak hanya dituntut sekedar dapat memproduksi Funding dan Lending tetapi juga dituntut untuk penawaran dan pelayanan yang lebih baik kepada pasar sasaran secara tepat dan efisien dibandingkan dengan yang ditawarkan para pesaingnya. Dari fenomena yang muncul serta yang di hadapi oleh BMT At-Tajdid Temayang Bojonegoro Dengan demikian maka sangat penting melakukan aktivitas strategi pemasaran guna dapat menentukan pasar mana yang akan menjadi sasaran produknya dengan begitu lembaga keuangan syariah di pandang masih perlu disosialisasikan secara luas. ${ }^{2}$

Hal-hal urgensi seperti produk, harga, tempat, dan promosi menjadi pertimbangan khusus dalam penelitian ini. Dikarenakan dalam sebuah lembaga empat hal tersebut menjadi wacana menarik untuk digali lebih dalam informasinya. Hal-hal urgensi yang menjadi pokok permasalah di BMT At-Tajdid Temayang Bojonegoro antara lain Rencana produk yang akan diterbitkan oleh BMT At-Tajdid Temayang Bojonegoro salah satunya adalah haji dan umroh. Meskipun sudah menjadi rencana dan sudah dipromosikan kepada umum, namun sepertinya hal ini masih menjadi keraguan bagi nasabah atau pihak lain, karena belum mendapatkan bukti konkrit.Untuk mengatasi permasalahan ini (membangun kepercayaan khalayak umum) pihak BMT At-Tajdid Temayang Bojonegoro berusaha meyakinkan secara perlahan dan memberikan gambaran

\footnotetext{
${ }^{2}$ Data RAT BMT At-Tajdid Temayang Bojonegoro.
} 


\section{Nur Musfiah, Ashlihah, Arivatu Ni'mati Rahmatika.}

bagaimana kedepannya dalam menyukseskan rencana produk tersebut.Pada intinya, pihak pengelola keuangan dan para nasabah atau calon nasabah saling menjaga kepercayaan/ amanah.

Dalam beroperasi mengelola keuangan mempunyai harga yang ditawarkan.Mulai dari harga bagi hasil tabungan, bagi hasil deposito, dan bagi hasil pembiayaan, terdapat perbedaan harga dengan lembaga keuangan lainnya. Pada lembaga keuangan selain BMT At-Tajdid Temayang Bojonegoromempunyai nisbahlebih rendah dari pada yang di tawarkan BMT At-Tajdid Temayang Bojonegoro sendiri. Namun di BMT mempunyai prosedur yang memudahkan untuk bertransaksi baik pembiayaan maupun tabungan. Sedangkan di lembaga lain mengalami prosedur yang terlalu rumit, Dan memberikan pengertian ini kepada para nasabah tentunya menjadi tugas pokok pihak BMT At-Tajdid Temayang Bojonegoro Temayang.

\section{B. METODE PENELITIAN}

\section{Batasan Istilah}

\section{a. Strategi Pemasaran}

Strategi pemasaran sangat penting terhadap pengoperasian suatu perusahaan, dimana dengan adanya strategi pemasaran maka usaha yang dijalankan oleh perusahaan mempunyai tindakan-tindakan jangka panjang yang mana mempunyai cara untuk mencapai tujuan perusahaan sehingga lebih terarah, direncanakan dan dipersiapkan lebih matang agar target yang 
dituju dapat tercapai. Strategi pemasaran terdiri dari strategi spesifik untuk pasar sasaran, penentuan posisi produk, bauran pemasaran, dan tingkat pengeluaran pemasaran. ${ }^{3}$

Dalam strategi pemasaran yang perlu diperhatikan adalah Product, yang penting diperhatikan dalam desain dan produk jasa BMT adalah atribut yang menyertai, seperti system, prosedur dan pelayanannya.Desain produk dan jasa BMT juga memperhatikan hal-hal yang berkaitan dengan ukuran bentuk dan kualitas.Yang selanjutnya Price. Pengertian harga dalam produk dan jasa BMT, berupa kontra prestasi dalam bentuk tingkat bagi hasil, baik untuk produk simpanan maupun pembiayaan.selanjutnyaPromotion. Kegiatan promosi dan produk pada jasa BMT pada umumnya dilakukan melalui media masa, atau televise. Konsep kegiatan promosi secara menyeluruh meliputi advertising, sales promotion, publicity and personal selling.Dan yang terakhir Place.Atau disebut juga saluran distribusi. Saluran distribusi produk dan jasa BMT, kantor pusat, yang secara langsung menyediakan produk dan jasa yang ditawarkan. Dengandemikian majunya teknologi, saluran distribusi dapat dilakukan melauin saluran telekominikasi seperti telepon dan jaringan internet. ${ }^{4}$

\section{b. Funding}

\footnotetext{
${ }^{3}$ Riadho, Wira Nur. Strategi PemasaranPembiayaan Pertanian. 2001, 67.

${ }^{4}$ Khabhibi, Ahmad. Pengaruh Penerapan Strategi Promosi ProdukSimpanan Pada BMT Amanah Ummah Sukoharjo.2010. 9.
} 


\section{Nur Musfiah, Ashlihah, Arivatu Ni'mati Rahmatika.}

Funding atau penghimpunan adalah dikatakan dalam kamus besar bahasa Indonesia berasal dari kata "himpun adalah berkumpul" ditambah dengan imbuhan "peng" menjadi penghimpunan yaitu "proses, cara, upaya menghimpun". ${ }^{5}$ Sedangkan maksud dari kata tersebut atau menurut penjelasannya adalah suatu kegiatan usaha yang dilakukan bank untuk mencari dana kepada pihak deposan yang nantinya akan disalurkan kepada pihak kreditur dalam rangka menjalankan fungsinya sebagai intermediasi antara pihak deposan dengan pihak kreditur. Prinsip yang digunakan ada dua bergantung dari jenis banknya yaitu Bank Konvensional dan Bank Syarie ${ }^{e h}$ dengan prinsip konvensional dan dengan prinsip syarieah.

\section{c. Lending}

Pembiayaan merupakan kerjasama antara lembaga dan nasabah dimana lembaga sebagai pemilik modal (shahibul maal) dan nasabah sebagai fungsi untuk menghasilakan usahanya. Pembiayaan menurut Undang-Undang Perbankan No. 7 tahun 1992 kemudian direvisi menjadi Undang-Undang Perbankan No. 10 tahun $1998 .^{6}$

\section{Jenis Penelitian}

Jenis Penelitian yang digunakan ini adalah penelitian lapangan (Field Research), yaitu melakukan kegiatan dilapangan tertentu guna memperoleh

\footnotetext{
${ }^{5}$ www.Google.Com, "Kamus Besar Bahasa Indonesia". DiaksesPukul 20.00.Wib, 20-09-2015.

${ }^{6}$ Ridwan, Muhammad, "Manajemen Baitul mal wa tanwil (BMT)", UII Press, Yogyakarta,2011, hal.163.
} 
berbagai data dan informasi yang diperlukan. ${ }^{7}$ Penelitian ini pada akhirnya akan dianalisa maka proses penelitian mengangkat data dari permasalahan yang ada dilapangan (lokasi penelitian) yang berkenaan dengan strategi pemasaran terhadap Funding dan Lending di BMT At-Tajdid Temayang Bojonegoro. Penelitian dilaksanakan di Desa papringan karena lokasi desa tersebut dekat dengan BMT At-Tajdid Temayang Bojonegoro Temayang.

Lokasi yang di pilih peneliti adalah BMT At-Tajdid Temayang Bojonegoro Temayang.Bojonegoro yang bertempat di lokasi MI Unggulan Temayang Kecamatan Temayang Kabupaten Bojonegoro.Variabel dalam penelitian ini adalah terdiri dari dua variabel bebas dan satu variabel terikat, maka sampel dalam penelitian ini adalah sebanyak 30 orang responden $(10 \times 3$ variabel $)$. Diambil dari 3007 populasi nasabah yang Funding dan Lending. Teknik pengumpulan data dalam penelitian ini adalah menggunakan teknik wawancara, kuisioner, dan dokumentasi.

\section{Analisis Regresi Linier Berganda}

$\mathrm{Y}=\mathrm{a}+\mathrm{b} 1 \times 1+\mathrm{b} 2 \times 2+\mathrm{b} 3 \times 3+\mathrm{b} 4 \times 4$

Dimana :

$\mathrm{Y}=$ Funding dan Lending

$\mathrm{X} 1=$ Produk

$\mathrm{X} 2=$ Harga

X3 = Tempat

X5 $=$ Promosi

$\mathrm{b} 1=$ Koefisien produk

${ }^{7}$ Sugiyono, Metodologi Penelitian Kuantitatif Dan Kualitatif (Bandung, 2013),. Hal 19. 
b2 = Koefisien harga

b3 = Koefisien tempat

b4 = Koefisien promosi

a $=$ Konstanta

\section{Uji Hipotesis}

a. Uji Parsial (Uji-t)

Pengujian ini dilakukan untuk mengetahui pengaruh masing-masing variabel independen secara parsial terhahap variabel dependen, ditunjukkan oleh tabel coefficient. Jika nilai signifikansi $>$ 0,05 maka keputusannya adalah ditolak atau variabel independen secara parsial tidak berpengaruh signifikan terhadap variabel dependen. Sebaliknya, jika nilai signifikansi < 0,05 maka keputusannya adalah diterima atau variabel independen. secara parsial berpengaruh signifikan terhadap variabel dependent. ${ }^{8}$

b. Uji Signifikansi Simultan (Uji F)

Uji f dalam analisis regresi linier berganda bertujuan untuk mengetahui pengaruh variabel independen terhadap variabel dependen secara simultan, yang ditunjukkan dalam tabel anova. Jika nilai signifikansi $>0,05$, maka keputusannya adalah ditolak atau variabel independen secara simultan tidak berpengaruh signifikan terhadap variabel dependen. Sebaliknya, jika nilai signifikansi < 0,05 maka keputusannya adalah terima atau variabel

\footnotetext{
8 Ali Muhson, Penerapan Metode Problem Sloving Dalam Pembelajaran Statistika Lanjut,(Yogyakarta: UNY,
} 2005 dalam skripsi wafiq Aziza) h. 70-73. 
independen secara simultan berpengaruh signifikan terhadap variabel dependen.

C. HASIL DAN PEMBAHASAN

\section{Analisis Regresi Linier Berganda}

\section{Tabel 1}

\section{Hasil Uji Regresi Linier Berganda Funding Coefficients $^{\mathrm{a}}$}

\begin{tabular}{|c|c|c|c|c|}
\hline \multirow{2}{*}{\multicolumn{2}{|c|}{ Model }} & \multicolumn{2}{|c|}{ Unstandardized Coefficients } & \multirow{2}{*}{$\begin{array}{c}\text { Standardized Coefficients } \\
\text { Beta }\end{array}$} \\
\hline & & $\mathrm{B}$ & Std. Error & \\
\hline \multirow{5}{*}{1} & (Constant) & .021 & 1.466 & \\
\hline & Produk & .559 & .151 & .601 \\
\hline & Harga & .334 & .159 & .307 \\
\hline & Tempat & .100 & .083 & .105 \\
\hline & Promosi & .003 & .128 & .002 \\
\hline
\end{tabular}

a. Dependent Variable: funding

Sumber : data diolah peneliti dengan IMB SPSS Statistic 21, 2019

Model Summary

\begin{tabular}{|l|r|r|r|r|r|}
\hline Model & \multicolumn{1}{|c|}{$\mathrm{R}$} & R Square & Adjusted R Square & $\begin{array}{c}\text { Std. Error of the } \\
\text { Estimate }\end{array}$ & Durbin Watson \\
\hline 1 &, $963^{\mathrm{a}}$ & .928 & .916 & .51932 & 1.590 \\
\hline
\end{tabular}

a. Predictors: (Constant), strategi(produk,harga,tempatdan promosi)

b. Dependent Variable Funding

Sumber : Data diolah peneliti dengan IMB SPSS 21, 2019

Dari tabel diatas, dapat diketahui bahwa besarnya koefisien determinasi (R square) atau kemampuan dari strategi pemasaran produk (X1), harga (X2), tempat (X3), promosi (X4) dalam menjelaskan serta memprediksi tentang variabel funding $(\mathrm{Y})$ juga menunjukan bahwa nilai koefisien determinasi (R square) sebesar 0,928, hal ini berarti 92,8\% dari Funding bisa dijelaskan oleh variabel 


\section{Nur Musfiah, Ashlihah, Arivatu Ni'mati Rahmatika.}

independen (strategi pemasaran). Sedangakan sisanya $(100 \%-92,8 \%=7,2 \%)$ dijelaskan oleh variabel lain yang tidak dimasukkan dalam model penelitian ini seperti poople, process dan physical evidencedan lain-lain.

\section{Tabel 2}

\section{Hasil Uji Regresi Berganda Lending}

Coefficientsa

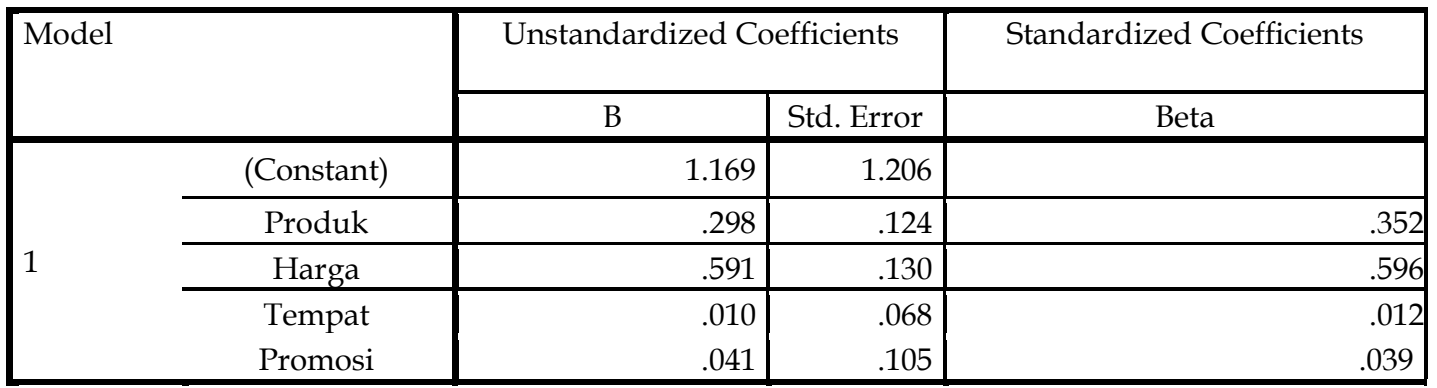

a. Dependent Variable: lending

Sumber : data diolah peneliti dengan IMB SPSS Statistic 21, 2019

Model Summary

\begin{tabular}{|l|r|r|r|r|r|}
\hline Model & \multicolumn{1}{|c|}{$\mathrm{R}$} & R Square & Adjusted R Square & $\begin{array}{c}\text { Std. Error of the } \\
\text { Estimate }\end{array}$ & Durbin Watson \\
\hline 1 &, $970^{\mathrm{a}}$ & .941 & .932 & .42697 & 1.541 \\
\hline
\end{tabular}

a. Predictors: (Constant), strategi(produk,harga,tempatdan promosi)

b. Dependent Variable Funding

Sumber : Data diolah peneliti dengan IMB SPSS 21, 2019

Dari tabel diatas, dapat diketahui bahwa besarnya koefisien determinasi

( $\mathrm{R}$ square) atau kemampuan dari strategi pemasaran produk (X1), harga (X2), tempat (X3), promosi (X4) dalam menjelaskan serta memprediksi tentang variabel funding $(\mathrm{Y})$ juga menunjukan bahwa nilai koefisien determinasi (R square) sebesar 0,941, hal ini berarti 94,1\% dari Lendingbisa dijelaskan oleh variabel independen (strategi pemasaran). Sedangakan sisanya $(100 \%-94,1 \%=5,9 \%)$ dijelaskan oleh variabel lain yang tidak dimasukkan dalam model penelitian ini seperti poople, process dan physical evidencedan lain-lain. 


\section{Uji Hipotesis (Uji F dan Uji T)}

Tabel 3

Hasil Uji FFunding

ANOVA $^{a}$

\begin{tabular}{|rl|r|r|r|r|r|}
\hline Model & & Sum of Squares & Df & Mean Square & F & \multicolumn{1}{c|}{ Sig. } \\
\hline \multirow{2}{*}{1} & Regression & 86.724 & 4 & 21.681 & 80.391 &, $000^{\mathrm{b}}$ \\
& Residual & 6.742 & 25 & .270 & & \\
& Total & 93.467 & 29 & & & \\
& & & & & & \\
\hline
\end{tabular}

a. Dependent Variable: funding

b. Predictors: (Constant), strategi

Sumber : Data diolah peneliti dengan IMB SPSS 21, 2019.

Berdasarkan Uji F pada tabel 4.20 menunjukan nilai $\mathrm{F}$ hitung sebesar 80,391 dengan $\mathrm{df} 1=$ derajat bebas pembilang 1 dan $\mathrm{df} 2=$ derajat bebas penyebut 28. Dan diperoleh bahwa nilai hasil $\mathrm{F}$ hitung $=80,391>$ dari $\mathrm{F}$ tabel $=$ 4,20 dengan tingkat signifikasi 0,00. Berdasarkan nilai tingkat signifikasi yang lebih kecil dari 0,05, maka model regresi dapat digunakan untuk memprediksi variabel independen Strategi pemasaran (produk, harga, tempat dan promosi) dengan demikian berpengaruh terhadap Funding. Dan berdasarkan kriteria penerimaan hipotesis menyatakan strategi pemasaran berpengaruh tidak signifikasi terhadap Funding yang artinya H0 diterima dan H1 ditolak.

Tabel 4

Hasil Uji F Lending

ANOVA $^{a}$

\begin{tabular}{|c|c|c|c|c|c|}
\hline Model & Sum of Squares & Df & Mean Square & $\mathrm{F}$ & Sig. \\
\hline Regression & 44,393 & 1 & 44,393 & 6,875 &, $014^{b}$ \\
\hline Residual & 180,807 & 28 & 6,457 & & \\
\hline Total & 225,200 & 29 & & & \\
\hline
\end{tabular}

a. Dependent Variable: Lending

b. Predictors: (Constant), strategi

Sumber : Data diolah peneliti dengan IMB SPSS 21, 2019 
Berdasarkan Uji F pada tabel 4.21 menunjukan nilai $\mathrm{F}$ hitung sebesar 6,875 dengan $\mathrm{df} 1=$ derajat bebas pembilang 1 dan $\mathrm{df} 2=$ derajat bebas penyebut 28. Dan diperoleh bahwa nilai hasil $\mathrm{F}$ hitung $=6,875>$ dari $\mathrm{F}$ tabel $=$ 4,20 dengan tingkat signifikasi 0,00. Berdasarkan nilai tingkat signifikasi yang lebih kecil dari 0,05, maka model regresi dapat digunakan untuk memprediksi variabel independen Strategi pemasaran (produk, harga, tempat dan promosi) dengan demikian berpengaruh terhadap Lending. Dan berdasarkan kriteria penerimaan hipotesis menyatakan strategi pemasaran berpengaruh tidak signifikasi terhadap Lendingyang artinya $\mathrm{H} 0$ diterima dan $\mathrm{H} 1$ ditolak.

\section{Tabel 5}

\section{Hasil Uji Parsial (Uji-t) Funding}

\begin{tabular}{|c|c|c|c|c|c|c|}
\hline \multicolumn{7}{|c|}{ Coefficients ${ }^{a}$} \\
\hline & \multirow[b]{2}{*}{ Model } & \multicolumn{2}{|c|}{ Unstandardized Coefficients } & \multirow{2}{*}{$\begin{array}{c}\begin{array}{c}\text { Standardized } \\
\text { Coefficients }\end{array} \\
\text { Beta }\end{array}$} & \multirow[t]{2}{*}{$\mathrm{T}$} & \multirow[t]{2}{*}{ Sig. } \\
\hline & & B & Std. Error & & & \\
\hline \multirow{5}{*}{1} & (Constant) & .021 & 1.466 & & 3.044 & .989 \\
\hline & Produk & .559 & .151 & .601 & 3.709 & .001 \\
\hline & Harga & .334 & .159 & .307 & 2.107 & .045 \\
\hline & Tempat & .100 & .083 & .105 & 2.205 & .240 \\
\hline & Promosi & .003 & .128 & .002 & 3.021 & .984 \\
\hline
\end{tabular}

a.Dependen Variabel Funding

Sumber : Data diolah peneliti dengan IMB SPSS 21, 2019.

Hasil uji hipotesis yang ditunjukkan pada tabel diatas, variabel strategi pemasaran produk mempunyai tingkat signifikasi sebesar 0,001 dan nilai $\mathrm{t}$ hitung sebesar 3,709 > t tabel sebesar 2,059, harga epunyai tingkat signifikasi sebesar 0,045 dan nilai t hitung sebesar 2,107 > t tabel sebesar 2,059, tempat mempunyai tingkat signifikasi sebesar 0,240 dan nilai $t$ hitung sebesar 
2,205 > t tabel sebesar 2,059 dan promosi tingkat signifikasi sebesar 0,984 dan nilai thitung 3,021 > t tabel sebesar 2,059. Hal ini berarti Ha diterima sehingga dapat dikatakan bahwa strategi pemasaran (produk, harga, tempat, dan promosi) berpengaruh signifikan terhadap funding di BMT At-Tajdid Temayang Bojonegoro.

\section{Tabel 6}

\section{Hasil Uji Parsial (Uji-t) Lending}

Coefficients ${ }^{a}$

\begin{tabular}{|l|c|c|c|c|c|}
\hline \multirow{2}{*}{ Model } & \multicolumn{2}{|c|}{ Unstandardized Coefficients } & $\begin{array}{c}\text { Standardized } \\
\text { Coefficients }\end{array}$ & \multirow{2}{*}{ Sig. } \\
\cline { 2 - 4 } & B & Std. Error & Beta & & \\
\hline
\end{tabular}

\begin{tabular}{|l|l|l|l|l|l|}
\hline (Constant) & 1.169 & 1.206 & & .970 & .341 \\
Produk & .298 & .124 & .352 & 2.406 & .024 \\
\hline Harga & .591 & .130 & .596 & 4.536 & .000 \\
\hline Tempat & .010 & .068 & .012 & 4.118 & .038 \\
\hline Promosi & .041 & .105 & .039 & 3.385 & .003 \\
\hline
\end{tabular}

a.Dependen Variabel Lending

Sumber : Data diolah peneliti dengan IMB SPSS 21, 2019.

Hasil uji hipotesis yang ditunjukkan pada tabel diatas, variabel strategi pemasaran produk mempunyai tingkat signifikasi sebesar 0,24 dan nilai $\mathrm{t}$ hitung sebesar 2,406 > t tabel sebesar 2,059, harga mempunyai tingkat signifikasi sebesar 0,000 dan nilai $\mathrm{t}$ hitung sebesar 4,536 > t tabel sebesar 2,059, tempat mempunyai tingkat signifikasi sebesar 0,038 dan nilai $\mathrm{t}$ hitung sebesar 4,118 > t tabel sebesar 2,059 dan promosi tingkat signifikasi sebesar 0,003 dan nilai t hitung 3,385 > t tabel sebesar 2,059. Hal ini berarti Ha diterima sehingga dapat dikatakan bahwa strategi pemasaran (produk, harga, 


\section{Nur Musfiah, Ashlihah, Arivatu Ni'mati Rahmatika.}

tempat, dan promosi) berpengaruh signifikan terhadap lending di BMT AtTajdid Temayang Bojonegoro.

Dari penelitian di atas dapat di peroleh :

Strategi pemasaran (produk, harga, tempat, dan promosi) memiliki pengaruh yang signifikan terhadap funding di BMT AT-Tajdid Temayang Bojonegoro dapat dilihat dari nilai variabel strategi pemasaran produk mempunyai tingkat signifikasi sebesar 0,001 dan nilai t hitung sebesar 3,709 sedangkan $\mathrm{t}$ tabel sebesar 2,059, harga mempunyai tingkat signifikasi sebesar 0,045 dan nilai t hitung sebesar 2,107 sedangkan $t$ tabel sebesar 2,059, tempat mempunyai tingkat signifikasi sebesar 0,240 dan nilai t hitung sebesar 2,205 sedangkan $\mathrm{t}$ tabel sebesar 2,059 dan promosi tingkat signifikasi sebesar 0,984 dan nilai t hitung sebesar 3,021 sedangkan $t$ tabel sebesar 2,059. Sehingga dapat disimpulan $\mathrm{HO}$ ditolak danHa diterima sehingga dapat dikatakan bahwa strategi pemasaran (produk, harga, tempat, dan promosi) berpengaruh signifikan terhadap funding di BMT At-Tajdid Temayang Bojonegoro.

Strategi pemasaran (produk, harga, tempat, dan promosi) memiliki pengaruh yang signifikan terhadap lending di BMT AT-Tajdid Temayang Bojonegoro dapat dilihat dari nilai variabel strategi pemasaran produk mempunyai tingkat signifikasi sebesar 0,024 dan nilai t hitung sebesar 2,406 sedangkan $\mathrm{t}$ tabel sebesar 2,059, harga mempunyai tingkat signifikasi sebesar 0,000 dan nilai $t$ hitung sebesar 4,536 sedangkan $t$ tabel sebesar 2,059, 
tempat mempunyai tingkat signifikasi sebesar 0,038 dan nilai t hitung sebesar 4,118 sedangkan $\mathrm{t}$ tabel sebesar 2,059 dan promosi tingkat signifikasi sebesar 0,003 dan nilai t hitung sebesar 3,385 sedangkan $t$ tabel sebesar 2,059. Sehingga dapat disimpulan $\mathrm{H} 0$ ditolakdan $\mathrm{Ha}$ diterima sehingga dapat dikatakan bahwa strategi pemasaran (produk, harga, tempat, dan promosi) berpengaruh signifikan terhadap lending di BMT At-Tajdid Temayang Bojonegoro.

Pengaruh strategi pemasaran (produk, harga, tempat, dan promosi) terhadap funding dan lendingyaitustrategi pemasaran produk (X1), harga (X2), tempat (X3), dan promosi (X4) dalam memprediksi variabel funding dan lending (Y) secara parsial dan simultan. Penelitian ini menghasilkan analisis regresi urutan besarnya pengaruh variabel independent secara berbeda-beda.Dapat dilihat dari nilai koefisien regresi yang pengaruhnya paling besar sampai yang mempunyai pengaruh kecil yaituharga dengan nilai sebesar (4.536) disusul dengan nilai dari tempat (4.118) disusul dengan nilai dari Promosi(3.385)disusul dengan nilai sebesar produk (2.406). Uji F sendiri terjadi pengaruh variabel strategi pemasaran (produk, harga, tempat, dan promosi secara bersama-samaatau simultan. Masing-Masing dari variabel ini adalah bersifat positif terhadap funding dan lendingdi BMT At-Tajdid Temayang Bojonegoro.

Prosentase pengaruhstrategi pemasaran (produk, harga, tempat, dan promosi) terhadap funding dan lendingberdasarkan kuisioner yang telah 


\section{Nur Musfiah, Ashlihah, Arivatu Ni'mati Rahmatika.}

disebarkan kepada nasabah oleh peneliti dan telah diuji oleh IBN SPSS Statistic 21 bahwa besarnya pengaruh strategi pemasaran (produk, harga, tempat, dan promosi) terhadap fundingsebesar 0,928, hal ini berarti 92,8\% bisa dijelaskan oleh variabel independen (strategi pemasaran). Sedangakan sisanya $(100 \%$ $92,8 \%=7,2 \%$ ) dijelaskan oleh variabel lain yang tidak dimasukkan dalam model penelitian ini seperti poople, process dan physical evidence dan lainlain.

Strategi pemasaran (produk, harga, tempat, dan promosi) terhadaplending sebesar 0,970 Ini menunjukan bahwa variabel strategi pemasaran terhadap lending di BMT At Tajdid Temayang mempunyai hubungan yang kuat. Hasil pada tabel diatas juga menunjukan bahwa nilai koefisien determinasi ( $\mathrm{R}$ square) sebesar 0,941, hal ini berarti 94,1\% dari lending bisa dijelaskan oleh variabel independen (strategi pemasaran). Sedangakan sisanya $(100 \%-94,1 \%=5,9 \%)$ dijelaskan oleh variabel lain yang tidak dimasukkan dalam model penelitian ini seperti poople, process dan physical evidence dan lain-lain.

\section{KESIMPULAN DAN SARAN}

Adanya pengaruh pada startegi pemasaran (produk, harga, tempat, promosi) terhadap funding dan lending di BMT At-Tajdid Temayang Bojonegoro, kemudian diuji kedalam SPSS dengan memperoleh hasil bahwafundingmempunyai nilai dari t hitung lebih besar dari nilai $t$ tabel, dimana 
nilai thitung produk sebesar 2,406 sedangkan $t$ tabel sebesar 2,059, harga t hitung sebesar 4,536 sedangkan $\mathrm{t}$ tabel sebesar 2,059, tempat $\mathrm{t}$ hitung sebesar 4,118 sedangkan $t$ tabel sebesar 2,059 dan promosi t hitung sebesar 3,385 sedangkan $t$ tabel sebesar 2,059.

Dan memperoleh hasil lendingt hitung produk sebesar 2,406 > t tabel sebesar 2,059, harga $t$ hitung sebesar 4,536 > t tabel sebesar 2,059, tempat $t$ hitung sebesar 4,118 $>\mathrm{t}$ tabel sebesar 2,059 dan promosi $\mathrm{t}$ hitung sebesar 3,385 $>\mathrm{t}$ tabel sebesar 2,059. Hal ini berarti H0 ditolak dan Ha diterima sehingga dapat dikatakan bahwa strategi pemasaran (produk, harga, tempat, dan promosi) berpengaruh signifikan terhadap lending di BMT At-Tajdid Temayang Bojonegoro.

Berdasarkan hasil pembahasan dan kesimpulan mengenai "pengaruh strategi pemasaran terhadap Funding dan Lending di BMT At Tajdid Temayang Bojonegoro, maka saran dari penulis sekiranya dapat bermanfaat untuk perkembangan BMT At-Tajdid Temayang Bojonegoro serta dapat memberikan masukan bagi lembaga, BMT At-Tajdid Temayang Bojonegoro memberikan pelatihan bagi karyawan/santri BMT At Tajdid demi meningkatkan minat nasabah terhadap funding dan lending di BMT At Tajdid Temayang Bojonegoro, Terutama peningkatan pada strategi pemasaran terhadap Lendingsehingga dapat menarik lingkungan masyarakat baik yang menjadi nasabah dan yang akan menjadi nasabah. 
Nur Musfiah, Ashlihah, Arivatu Ni'mati Rahmatika.

\section{E. DAFTAR PUSTAKA}

Data RAT BMT At-Tajdid Temayang Bojonegoro.

Khabhibi, Ahmad. Pengaruh Penerapan Strategi Promosi ProdukSimpanan Pada BMT Amanah Ummah Sukoharjo. 2010.

Muhson, Ali. Penerapan Metode Problem Sloving Dalam Pembelajaran Statistika Lanjut. Yogyakarta: UNY, 2005.

Ni'mati Rahmatika, Arivatu dan Dunyati Ilmiah, "Analisis Sharih Akad Mudrobah dan Bay pada Sertifikat Investasi Mudharabah Antar Bank (SIMA)" dalam Proceedings of Annual Conference for Muslim Scholars, no. 1, 65-72, 2017.

Riadho, Wira Nur. Strategi PemasaranPembiayaan Pertanian. 2001.

www.Google.Com, “Kamus Besar Bahasa Indonesia”. DiaksesPukul 20.00.Wib, 20-09-2015.

Ridwan, Muhammad, "Manajemen Baitul mal wa tanwil (BMT)", UII Press, Yogyakarta, 2011.

Sugiyono, Metodologi Penelitian Kuantitatif Dan Kualitatif. Bandung. 2013. 